\title{
EXPLORING FRONTLINE EMPLOYEES' MOTIVATIONS TO ENGAGE IN VALUE COCREATION: A CONTEXT OF NON-FUEL RETAILING
}

\author{
Muhammad Amin ${ }^{1}$, Amjad Shamim ${ }^{1,}$ Zulkipli bin Ghazali ${ }^{1}$ \\ Management \& Humanities department, Universiti Teknologi PETRONAS, Malaysia
}

\begin{abstract}
In the context of non-fuel retailing, the goal of this study is to find out what motivates frontline employees to participate in value cocreation activities with consumers. According to this study, frontline employees participate in value cocreation activities to attain the expected or perceived value they desire. Through the conduction of six interviews in Malaysia's automotive sector, this study used an exploratory technique to investigate the underlying characteristics of frontline employees' motives. Semi structured interviews were done with the use of a topic guide, but the researchers were not confined in their frame of reference, allowing them to explore for clarification and confirmation. The results of the interviews were examined using an idiographic technique and then compared using cross-case analysis. Professional identity, financial benefits, career progression opportunities, and workplace recognition are all motivators for frontline employees to cocreate value. Due to variances in the employees' past expectations, these reasons may change across different service situations. Managers may begin measuring and managing service interactions between frontline personnel and customers by understanding their motives to cocreate value.
\end{abstract}

Keywords: Frontline employees; Motivation; value cocreation; Expectancy theory; Exploratory study.

\section{INTRODUCTION:}

The rise of service dominant logic (SD-logic) has widely grasped the scholars and practitioners' interest towards value cocreation (VCC). The application areas of VCC include design and development of new goods and service (Hoyer, Chandy, Dorotic, Krafft, \& Singh, 2010), collaboration with users as innovators (Bogers, Afuah, \& Bastian, 2010) efforts of users in customizing products to their needs (Syam \& Pazgal, 2013), presumption (Xie, Guan, \& Huan, 2019), co-production (Etgar, 2008), participatory roles of consumers, communities, and crowd (Ind \& Coates, 2013), retailing (Andreu, Sánchez, \& Mele, 2010), knowledge, learning and solutioning within business networks (Hakanen, 2014), multi-firm partnerships (Ceccagnoli, Forman, Huang, \& $\mathrm{Wu}, 2012$ ) open business models (Chesbrough \& Brunswicker, 2013), and service exchange and service systems. 
However, previous researchers' investigation and conceptual treatment of VCC has narrowed its focus only in customers domain, by ignoring the important role other actors especially frontline employees. Frontlines employees are the ones who have regular direct service interaction with customers. Therefore, it has been argued that during the direct service interaction if FLEs don't support or engage in the customers' value creation process, value cannot be cocreated (Karlsson \& Skålén, 2015). Singh, Brady, Arnold, and Brown (2016) have in their respective research considered FLEs as the most important sources of VCC towards sustainable and efficient VCC process. Therefore, by taking the importance of this point, this paper sets out to contribute to our understanding what motivate the FLEs to engage in service interaction with the customers to cocreate the value.

Apart from this, a multitude of previous studies have noticed the topic of motivation in cocreation but most of them are limited to the investigation from customers perspective such as customers motivation to engage in cocreation in various service providing contexts such as healthcare, financial services, retail, luxury brands, transportation, and tourism (Anh \& Thuy, 2017; Echeverri \& Skålén, 2011; Grissemann \& Stokburger-Sauer, 2012). As, customers' motives are led by their intrinsic motivations scuh as fun and enjoyment (Füller, 2010). These motives mainly drive customers attitudinal and behavioral intentions towards engagement in value cocreation (Petri \& Jacob, 2016). Notwithstanding, the customer perspective on value cocreation is important for investigation, however, without the FLEs support and participation, the value cannot be cocreated with customers.

The understanding of the frontline employees motivation to cocreate value (EMCCV) is very important as motivation strengthen the cocreation efforts (R. Findsrud, B. Tronvoll, \& B. Edvardsson, 2018) and is vital as it illuminates the how and to what extent FLEs leverage their knowledge and skills (Locke \& Latham, 2004) to cocreate the value. A better understanding about the FLEs motivation to cocreate value is key to develop better service experinces that can be suitable to promote VCC in service firms. Therefore, exploring the VCC from FLEs perspective, with specific focus on what motivates them to cocreate the value during the service interactions with the customers is critical to the development of VCC understanding. So, this study aim to fill this gap by exploring and frontline employees' motivation to cocreate the value. 


\section{THEORETICAL BACKGROUND}

\section{Frontline employees' motivation to cocreate value (EMCCV)}

VCC happens during the service interaction between actors (employees and customers) where they integrate their resources (knowledge and skills) as part of the VCC process to create value for each other (Caridà, Edvardsson, \& Colurcio, 2019). Although during the service interaction, actor's knowledge and skills could empower their resource integration, however, that is not enough for VCC to happen. Since knowledge and skills do not generate value but their use, therefore, actors must be motivated to use the knowledge and skills to cocreate value. Prior literature explains that an individual motivation to engage in service interaction is likely to trigger by some form of personal needs (Neghina, Caniëls, Bloemer, \& van Birgelen, 2015) or experience (Holbrook, 2006). Expectancy theory of motivation suggests that actors behavioural engagement is influenced by expectations of achieving desirable outcomes (Chiang \& Jang, 2008).

\section{METHODOLOGY}

\section{Study design and data collection}

Discovery-oriented research objectives demands to use the phenomenological interviewing (Fournier, 1998)where the purpose is to explore what actor (FLEs) wants to get out from service interactions with the customers. By gaining the understanding of the FLEs motivations towards service interaction, interviewing approach is also helpful to understand the process of VCC. The research questions asked from FLEs are what they perceive or expect as value for themselves at the end of service interactions with customers. What encourages them to have better service interaction with the customers to cocreate the value? what are their specific concerns towards the healthy interaction between them and customers? What motivates them to engage the customers towards VCC. Accordingly, in-depth interviews were conducted with 12 frontline employees from four automotive service centres of two states of Malaysia (Perak, Kuala Lumpur).

To identify and recruit the FLEs, we took the help of key member of Malaysian automotive association. This member has possessed a vast experience in automotive service industry and is an active member of Malaysian automotive association. He recommended us twenty FLEs from different states. The FLEs were contacted through email and phone call. After the confirmation from them we were able to get the interviews of six frontline employees. All of them were either senior or falls in master category. We interviewed everyone independently from 45-60 minutes, without paying any financial compensation to them. All 
the interviews were recorded and transcribed. Before interview, each FLE was told that their information would remain anonymous and after the analysis of all interviews, the findings were subjected to scrutiny to FLEs from whom the findings were based to ensure authenticity (Hirschman, 1986).

\section{Data analysis}

To develop an understanding about the FLEs motives to cocreate value requires two types of interpretation interview transcripts (Fournier, 1998). Both types of interpretation follow the grounded theory (Glaser \& Strauss, 1967). The step in the interpretation stars from the idiographic analysis of the interviews that starts from reading through transcripts and looking for recurring behaviour and types of responses. The second step involves across-person analysis to learn patterns of each respondent. These steps helped us to understand the FLEs motives to cocreate value in automotive service industry of Malaysia.

\section{Idiographic Analysis}

Idiographic analysis provide the summary and findings of every respondents (Fournier, 1998). Following sections will explain about the summary and findings of six FLEs who participated in interviews. The summary includes their gender, race, education, job experience, current position and their expected motives towards VCC interactions. Idiographic analysis was compared with the cross-case analysis.

\section{Frontline employee one -- six}

The following Table 1 explains about the summary of six frontline employees' who participated in interviews.

Table 1: Respondents’ Demographic

\begin{tabular}{lll}
\hline Variables & & Frequencies \\
\hline Gender & Male & 3 \\
& Female & 3 \\
\hline Nationality & Malaysians & 6 \\
& Others & 0 \\
\hline Race & Malay & 2 \\
& Chinese & 2 \\
& Indian & 2 \\
& Others & 0 \\
\hline Education & Certificate & \\
& Diploma & 5 \\
& Degree & 1 \\
\hline Working Experience & $5-7$ years & 1 \\
& $8-10$ years & 3 \\
\hline
\end{tabular}




\begin{tabular}{lll}
\hline & above 10 years & 2 \\
\hline Position & $\begin{array}{l}\text { Junior Level } \\
\text { Senior Level }\end{array}$ & 6 \\
\hline
\end{tabular}

During interviews with FLEs of automotive service centers it was interesting to learn that some service centers act proactively towards the FLEs developmental growth. Administration of their service centers has arranged regular training programs after every two months. Administration takes these steps to enhance FLEs desired goals of development regarding their knowledge and skills to enhance their professional identity. Few service centers gradually shift their FLEs duties with mechanics to enhance their understanding of the different maintenance work and technological advancement and even send them abroad for professional growth in the parent organization. Due to these types of professional growth programs FLEs perform their roles more actively and become a source of competitive advantage. During the interviews we noted the FLEs concerns about financial rewards. Few shared their thoughts that parent companies of service centers give bonuses or extra financial benefits to their service centers after the achievement of targets, but unfortunately owners of service centers don't pay their bonuses to them. So, from these types of FLEs views, we extract that financial motives are the ones that can boost the engagement of employees in VCC.

Furthermore, one of the respondents stated that we experience various sorts of stress from time to time, but that our boss helps to alleviate these stressors by his sensible actions. Our boss, for example, is continuously notifying the upper administration about our exceptional job, which satisfies our recognition needs. One of the front line workers stated that recognition is something that cannot be linked to financial motivations. One of the most crucial motivators for employees, we discovered, is career consideration. One high performer expressed his belief that numerous things contribute to his high performance, but that the current service centre where he works today provides more job prospects than others. Even one of the front-line workers stated that he left his former job due to a lack of career chances, whereas his prior employer was more focused on developmental help.

\section{Cross-case analysis}

After the compilation of FLEs motivation towards VCC, four motives were identified. Four motives include professional identity, financial benefits, recognition and career opportunity motives. Following section explain about the identified motives. 


\section{Professional Identity (PI)}

To enhance the employees' motivation in VCC activities, PI is considered as an important dimension. FLEs who want to improve their PI should be more motivated to connect with customers for cocreation of value because they understand that creating value for customers is the centre of their profession, not just meeting service delivery requirements. These personnel desire to establish their own identity within the company and want to advance in their careers. According to previous research, PI assists FLEs in achieving autonomy while engaging with customers (Boyle, 2020).

\section{Financial motives (FM)}

The second component is financial motivations (FM), which refers to monetary benefits that FLEs expect from management in exchange for providing great service to clients during service encounters. This dimension is measured using four different elements. This dimension is what propels healthy service interactions between FLEs and customers toward VCC - for example, rewarding FLEs with bonuses or extra-economic benefits for providing exceptional solutions to customers and turning them into repeat customers can encourage FLEs to continue providing such service. FLEs expect greater financial benefits for extra efforts in engaging consumers and assisting them in the value creation process.

\section{Recognition Motives (RM)}

Recognition motivations (RM) are the third dimension that explains how someone's efforts are respected, appreciated, and acknowledged at the corporate level and within the customer community. Previous research has found that gratitude and courteous treatment motivate FLEs to participate in VCC (Palma et al. 2019). Similarly, this study found that recognition is critical for encouraging FLEs, particularly when dealing with dissatisfied clients during service interactions and converting them into loyal customers. Recognition is beneficial in building a pleasant environment in which to communicate with customers.

\section{Career opportunities Motives (COM)}

Employees' expectations regarding future work chances that meet their career objectives may be conceptualised using career opportunities motives (COM). This is the dimension where FLEs aim to demonstrate that they are the best in service delivery and collaborate with consumers to create value for them. Customers respect them since they are at the frontline of service delivery, therefore displaying capabilities and obtaining a chance for promotion might be favourably acknowledged. The more 
delighted customers are with the service, the more opportunity FLEs will have to demonstrate their expertise. As a result, it directs their professional development and paves the way for future advancement.

\section{DISCUSSION}

This research highlights the understanding and importance of FLEs motivation towards VCC. The findings regarding the important role of EMCCV is also relevant to R. Findsrud, B. Tronvoll, and B. J. M. T. Edvardsson (2018) who suggest that traditional understanding of operant resources which overlooked motivation, is insufficient to describe VCC. Furthermore, according to this study, value is not only related to evaluating outcomes but evaluating value prior in process and after cocreation. FLEs motivation changes over time based on the FLEs role and engagement. Human nature is complex where every individual needs and motivation vary according to the different circumstances (Schein, 1980). For instance, FLEs motivations may vary according to experience, expectations and age. Rowley (1996, p. 11) suggest that "the effective manager needs to recognize that different motivators are appropriate for different staff and that different staff will demonstrate differing inherent levels of motivation in setting their own targets and striving towards them." It has been noted that different automotive brands boost their FLEs motivation through different strategies and these strategies help the service firms to retain their engagement during service interaction.

\section{Acknowledgement}

This research is funded by Yayasan Universiti Teknologi PETRONAS Fundamental Research Grant. Titled “Envisioning Future Petrol Station: Customers' Value-in-Experience Model for PETRONAS Dagangan Berhad Non-Fuel Retailing” cost center 015LC0-202.

\section{REFERENCES}

Andreu, L., Sánchez, I., \& Mele, C. (2010). Value co-creation among retailers and consumers: New insights into the furniture market. Journal of Retailing and Consumer Services, 17(4), 241-250.

Anh, P. N. T., \& Thuy, P. N. (2017). The effects of interaction behaviors of service frontliners on customer participation in the value co-creation: a study of health care service. Service Business, 11(2), 253-277.

Bogers, M., Afuah, A., \& Bastian, B. (2010). Users as innovators: A review, critique, and future research directions. Journal of management, 36(4), 857-875. 
Boyle, K. (2020). Autonomy and the instrumental music teacher: negotiating culture in professional practice. PRACTICE, 2 (1), 1-18.

Caridà, A., Edvardsson, B., \& Colurcio, M. (2019). Conceptualizing resource integration as an embedded process: Matching, resourcing and valuing. Marketing Theory, 19(1), 65-84.

Ceccagnoli, M., Forman, C., Huang, P., \& Wu, D. (2012). Cocreation of value in a platform ecosystem! The case of enterprise software. MIS quarterly, 263-290.

Chesbrough, H., \& Brunswicker, S. (2013). Managing open innovation in large firms. Stuttgart: Fraunhofer Institute for Industrial Engineering.

Chiang, C. F., \& Jang, S. S. (2008). An expectancy theory model for hotel employee motivation. International Journal of Hospitality Management, 27(2), 313-322.

Echeverri, P., \& Skålén, P. (2011). Co-creation and co-destruction: A practice-theory based study of interactive value formation. Marketing theory, 11(3), 351-373.

Etgar, M. (2008). A descriptive model of the consumer co-production process. Journal of the Academy of Marketing Science, 36(1), 97-108.

Findsrud, R., Tronvoll, B., \& Edvardsson, B. (2018). Motivation: The missing driver for theorizing about resource integration. Marketing Theory, 18(4), 1-27.

Findsrud, R., Tronvoll, B., \& Edvardsson, B. J. M. T. (2018). Motivation: The missing driver for theorizing about resource integration. 1470593118764590.

Fournier, S. (1998). Consumers and their brands: Developing relationship theory in consumer research. Journal of consumer research, 24(4), 343-373.

Füller, J. (2010). Refining virtual co-creation from a consumer perspective. California management review, 52(2), 98-122.

Glaser, B., \& Strauss, A. (1967). The discovery of grounded theory. 1967. Weidenfield \& Nicolson, London, 1-19.

Grissemann, U. S., \& Stokburger-Sauer, N. E. (2012). Customer co-creation of travel services: The role of company support and customer satisfaction with the co-creation performance. Tourism Management, 33(6), 1483-1492.

Hakanen, T. (2014). Co-creating integrated solutions within business networks: The KAM team as knowledge integrator. Industrial Marketing Management, 43(7), 1195-1203.

Hirschman, E. C. (1986). Humanistic inquiry in marketing research: philosophy, method, and criteria. Journal of marketing Research, 23(3), 237-249.

Holbrook, M. B. (2006). Consumption experience, customer value, and subjective personal introspection: An illustrative photographic essay. Journal of Business Research, 59(6), 714-725. 
Hoyer, W. D., Chandy, R., Dorotic, M., Krafft, M., \& Singh, S. S. (2010). Consumer cocreation in new product development. Journal of Service Research, 13(3), 283-296.

Ind, N., \& Coates, N. (2013). The meanings of co-creation. European Business Review, 25(1), 86-95.

Karlsson, J., \& Skålén, P. (2015). Exploring front-line employee contributions to service innovation. European Journal of Marketing, 49(9/10), 1346-1365.

Locke, E. A., \& Latham, G. P. (2004). What should we do about motivation theory? Six recommendations for the twenty-first century. Academy of management review, 29(3), 388-403.

Neghina, C., Caniëls, M. C., Bloemer, J. M., \& van Birgelen, M. J. (2015). Value cocreation in service interactions: Dimensions and antecedents. Marketing Theory, 15(2), 221242.

Petri, J., \& Jacob, F. (2016). The customer as enabler of value (co)-creation in the solution business. Industrial Marketing Management, 56, 63-72. doi:10.1016/j.indmarman.2016.03.009

Rowley, J. (1996). Motivation and academic staff in higher education. Quality assurance in education.

Schein, E. H. (1980). Intergroup problems in organizations. Organizational Psychology, Englewood Cliffs, NJ: Prentice-Hall, 172-181.

Singh, J., Brady, M., Arnold, T., \& Brown, T. (2016). The Emergent Field of Organizational Frontlines. Journal of Service Research, 20(1), 3-11. doi:10.1177/1094670516681513

Syam, N. B., \& Pazgal, A. (2013). Co-creation with production externalities. Marketing Science, 32(5), 805-820.

Xie, L., Guan, X., \& Huan, T.-C. (2019). A case study of hotel frontline employees' customer need knowledge relating to value co-creation. Journal of Hospitality and Tourism Management, 39, 76-86. 